\title{
Are Long Fire-free Periods Needed to Maintain the Endangered, Fire-recruiting Shrub Arctostaphylos morroensis(Ericaceae)?
}

\author{
$\underline{\text { Dennis Odion }}^{1}$ and Claudia Tyler ${ }^{1}$
}

\begin{abstract}
Morro manazanita (Arctostaphylos morroensis) is a distinctive shrub restricted to a small area along the coast of California, USA. This endangered species faces two opposing fire-related extinction risks: (1) adults are killed by fire, and (2) recruitment opportunities only occur with fire. These strongly limit the capacity of this, as well as other obligate-seeding species, to recover from a population decline, which may result if there is an inadequate amount of time between fires for replenishment of sufficient seed populations. Using a prescribed burn, we tested whether the size of the seed bank that had accumulated in a 40-yr-old stand would prove adequate for maintaining A. morroensis population sizes through fire. Prior to the burn, we found $\sim 11,000$ seeds $/ \mathrm{m}^{2}$ in the soil, mostly in the top $5 \mathrm{~cm}$. However, the number of viable seeds was substantially lower $\left(334 \mathrm{seeds} / \mathrm{m}^{2}\right)$, and less than one-third of these survived the experimental fire $\left(99 \mathrm{seeds} / \mathrm{m}^{2}\right)$. Germination occurred only in the first two wet seasons after the fire, and may have been adequate to replace the number of $A$. morroensis present before the burn. However, most seedlings did not survive their initial summer drought. After three years, the new population of A. morroensis was less than half the size of the parent population. Further mortality is expected because the remaining seedlings are highly clumped. We conclude that A. morroensis may require considerably longer than 40 years to establish an adequate seed bank to compensate for mortality and prevent population decrease or local extinction. This prolonged risk is perhaps explained by specialization of this species to a historic regime of relatively infrequent fire. There are many obligate-seeding species in fire-prone shrublands that may not be resilient to a regime of fire more frequent than that with which they evolved.
\end{abstract}

\section{INTRODUCTION}

The conservation and management of fire-prone shrublands, such as California chaparral, pose difficult challenges (Keeley 1993, Keeley et al. 2000). Many species found in these systems are dependent on fire to trigger germination from a dormant seed bank in order to produce offspring (Tyler 1995). Yet, it may not be possible for managers to accommodate the highintensity, stand-replacing fires that have maintained these species, especially near human development. In other areas, frequent human ignitions have resulted in fire-free periods that are too short for species that must accumulate a seed bank over time (Keeley et al. $1999 b$ ). Understanding the resilience of threatened species to alterations in natural fire regimes is a key issue for conservation (Bond and van Wilgen 1996, Auld and Denham 2001).

This may be especially critical for fire-recruiting, nonsprouting shrubs such as the endangered Morro manzanita (Arctostaphylos morroensis Weisl. \& Schreiber). This genetically distinct species is restricted to about 350 fragmented ha of maritime chaparral at the south end of Morro Bay, San Luis Obispo County, California, USA (Mullany 1990). Based on risk assessment criteria developed by the World Conservation Union (IUCN 1994) and amended by Keith (1998), A. morroensis may be categorized as facing an extremely high risk of extinction, especially considering its life history attributes.

Unlike more fire-prone environments supporting chaparral (Keeley et al. 1999a), fire has been effectively eliminated in A. morroensis vegetation by modern suppression. This is a potential conservation concern because seedling establishment of $A$. morroensis does not effectively take place in the absence of fire or land clearing (C. Tyler and D. Odion, unpublished data). Eventually, fire may be required for this species to be maintained. However, prescribed burning presents a risk because, unlike

${ }^{1}$ University Marine Science Institute, University of California, Santa Barbara 
many shrubs, the obligate-seeder $A$. morroensis cannot resprout. Its populations are completely eliminated by fire, and must reestablish from seeds that survive fire.

Postfire establishment of A. morroensis is dependent on several factors, namely sufficient viable seed densities and survivorship of seeds and seedlings. Although its seed densities can be relatively high, up to 45,000 seeds $/ \mathrm{m}^{2}$ in dense, monospecific stands, viabilities are generally very low, from $1 \%$ to $5 \%$ (C. Tyler and D. Odion, unpublished data). If viable seed densities in the soil are too low because the fire-free period has not been long enough for adequate seed banks to accumulate, populations of this shrub may suffer reduction or local extinction. This has been termed "immaturity risk" by Zedler (1995) and has been documented for a number of chaparral-associated species (Zedler et al. 1983, Keeley et al. 1999b, Ne'eman et al. 1999) as well as obligate seeders in South Africa and Australia (Bond and van Wilgen 1996, Enright et al. 1996, Russell-Smith et al. 2002). The size of the effective seed bank in chaparral species is also reduced by fire, when substantial seed mortality may occur (Borchert and Odion 1995, Odion and Davis 2000). Also, mortality of seedlings can be high following germination, as many succumb to moisture stress during the long summer drought that is characteristic of the chaparral environment (Frazer and Davis 1988, Tyler and D'Antonio 1993 [See Erratum]).

To determine the effect of burning on seedling establishment and to assess immaturity risk in $A$. morroensis, we made observations in a 40-yr-old stand that was burned in a prescribed fire. We determined preburn seed densities and seed viabilities, and seed mortality due to fire, as well as postfire germination and seedling survivorship for three years, to compare the population that established after the burn with the one present before.

\section{METHODS}

\section{Study site}

We conducted this research in Montaña de Oro State Park, San Luis Obispo County, California, USA. The substratum at the site is Pleistocene eolian sand mapped as Baywood fine sandy loam (Soil Conservation Service 1984). The climate is mediterranean, with mild, dry summers and cool, moist winters. Fog is common. Mean annual rainfall is $575 \mathrm{~mm}$ and is usually expressed as the amount from 1 July through the following 30 June. Total precipitation (as recorded at the nearest National Weather Service recording station) for 1998 - 1999, 1999 - 2000, and 2000 - 2001 was $415 \mathrm{~mm}, 634 \mathrm{~mm}$, and $623 \mathrm{~mm}$, respectively (Fig. 1). The vegetation cover at the site was approximately $40 \%$ A. morroensis, $5 \% \quad Q$. agrifolia, and the remainder a mixture of open chaparral dominated by widespread shrubs (Ceanothus cuneatus and Adenostoma fasciculatum, ) coastal sagedune scrub species (Ericameria ericoides and Salvia mellifera), and grassland dominated by the invasive exotic Ehrharta calycina. The area was previously burned and cleared of shrubs in 1958 by the U.S. Army Corps of Engineers during ordnance removal. We confirmed that the A. morroensis stand was $40 \mathrm{yr}$ old at the time of the prescribed burn in November 1998 by analyzing rings on cross sections of shrubs that were cut to establish the burn perimeter.

Fig. 1. Monthly rainfall during the first three growing seasons after the 1998 prescribed burn, as well as the 96-yr average Data are from the National Weather Service station in San Luis Obispo, California, USA (about $20 \mathrm{~km}$ northeast of the study site).

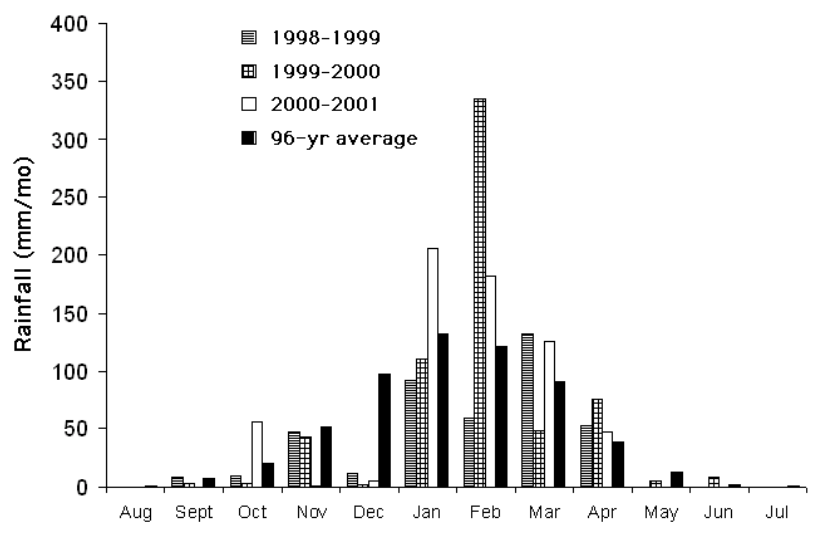

Prior to the burn, we established 24 circular plots permanently marked at the centers. Of these, 13 were located in dense patches of A. morroensis. The others were for evaluating seedling recruitment outside these patches. Nine of the A. morroensis plots were located at 5-m intervals along either side (randomly chosen) of a transect. These plots were randomly placed from 1 to $10 \mathrm{~m}$ in a perpendicular direction from the transect line. The remaining A. morroensis plots were randomly located inside or near the edge of monospecific patches. For plots located outside patches, eight were placed along a transect, as previously described, in adjacent coastal scrub and grassland, and the remaining three were randomly 
located in chaparral dominated by Adenostoma and Ceanothus.

\section{Seed banks}

To determine the size and viability of the $A$. morroensis seed bank, we collected soil samples from under adult shrubs in 1995 and again in 1998 before and after the prescribed burn. In 1995, we collected six soil cores (each $7.1 \mathrm{~cm}$ in diameter) from under each of five A. morroensis plants. After removing litter from the soil surface, we inserted the corer vertically to a depth of $10.3 \mathrm{~cm}$. We kept the top and bottom halves of the cores separate to determine the relative seed densities and viabilities at these depths. In 1998, we collected four soil cores from under each of seven A. morroensis plants (in seven of the above-mentioned permanent plots); samples were collected (1) one month before the burn at a distance of $0.8 \mathrm{~m}$ from the center stake, and (2) one week following the burn at a distance of $1.0 \mathrm{~m}$ from the center stake.

Samples were sifted through a Number 12 USA Standard Testing Sieve (mesh size $1.70 \mathrm{~mm}$ ). We retrieved intact seeds by hand from the mix of remaining particles. We cut open all seeds from 1995 and 1998 preburn samples soon after they were collected and examined the chamber for viable embryos, using a dissecting microscope. Embryos that were white and fleshy were counted as viable (Keeley 1977). Some appeared to be waxy and may have been somewhat desiccated. The remaining seeds, scored inviable, contained some papery residue of an embryo or exhibited an empty chamber with no evidence of a residual embryo. Our method ensured that we obtained an upper estimate of potentially viable seed, because some seeds scored as viable may not have been. However, evidence from related studies (C. Tyler and D. Odion, unpublished data) indicates that our estimates of viability are accurate since, with some treatments, we obtained germination percentages equivalent, or nearly so, to our estimated viability percentages.

In the laboratory, seeds collected in 1998 from postburn samples were placed on moist filter paper in growth chambers, kept at a constant temperature of $20^{\circ} \mathrm{C}$, and monitored for germination for $95 \mathrm{~d}$. Previous germination studies indicated that no germination would occur beyond this period (C. Tyler and D. Odion, unpublished data). We then assessed viability of ungerminated seeds by cutting them open and examining embryos.

\section{Burn characteristics}

Light rainfall (approximately $1 \mathrm{~cm}$ ) occurred $10 \mathrm{~d}$ prior to the burn on 25 October 1998. Soils under A. morroensis appeared dry, probably because the moisture did not penetrate the relatively deep litter layer. Significantly reduced germination occurs when seed of A. morroensis is soaked in water for $24 \mathrm{~h}$ prior to a fire treatment (C. Tyler and D. Odion, unpublished data).

Fig. 2. Photograph of a prescribed burn in progress. The longest flames $(\sim 15 \mathrm{~m})$ are in dense patches of Arctostaphylos morroensis. The utility pole in the lower right foreground is $\sim 10 \mathrm{~m}$ tall.

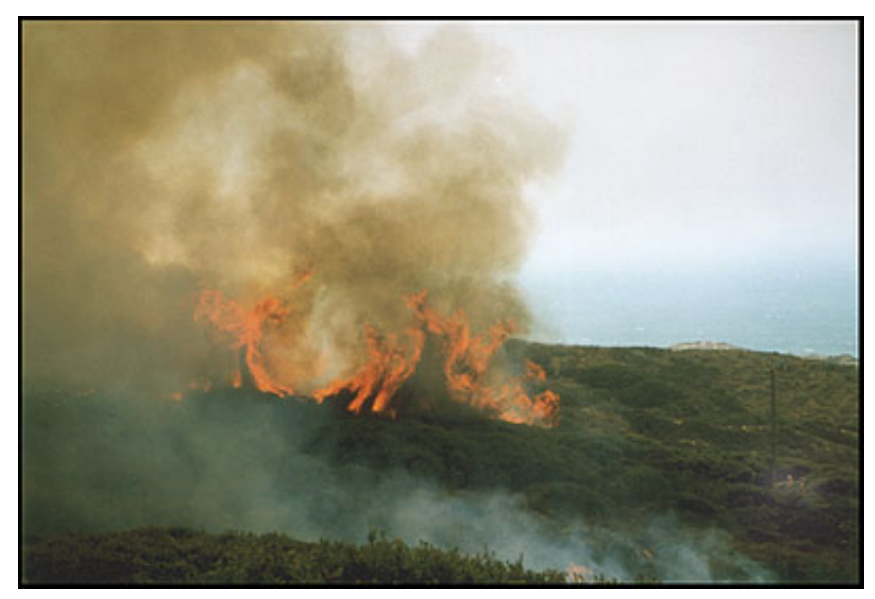

The prescribed burn was conducted on 4 November 1998. The air temperature remained about $16^{\circ} \mathrm{C}$ while the fire was actively burning, and relative humidities ranged from $50 \%$ to $60 \%$. Although fire behavior was subdued by these mild atmospheric conditions, there were still flame lengths as great as $\sim 15 \mathrm{~m}$ in the dense A. morroensis patches (Fig. 2). Flaming combustion in these patches lasted $\sim 2$ min and was followed by smoldering of litter and other oxygen-deprived ground fuels. This continued into the following day in the deepest litter. We observed no collapse and combustion of $A$. morroensis canopy on the ground, as has been observed in mixed chaparral (Craddock 1929) and chamise chaparral (Odion and Davis 2000). In some spots, litter was still smoldering after $24 \mathrm{~h}$, and soils were still warm to hot in plots where $A$. morroensis had been. Based on our observations, as well as previous research (Hartford and Fransden 1992), it appears that most of the soil heating resulted from the prolonged smoldering of the deep litter under A. morroensis. 
Table 1. Results (mean $+1 \mathrm{SE}$ ) of seed bank sampling in the prescribed burn area $(1995, n=5 ; 1998, n=7)$ for the total number of intact seeds $/ \mathrm{m}^{2}$, the number of viable seeds $/ \mathrm{m}^{2}$, and the percentage of viability in samples from the top $5 \mathrm{~cm}$ of soil and next $5 \mathrm{~cm}$ of soil below that. Asterisks indicate a significant difference between top and bottom samples (paired $t$ tests, $P<0.05)$.

No. intact seeds $/ \mathrm{m}^{2}$

Period Top $5 \mathrm{~cm} \quad$ Botto

Preburn

$-1995$

Preburn

$-1998$

Postbur

n-1998
$12491 *(2061)$

$8568 *(1638)$

7900* (859)
$5 \mathrm{~cm}$

2732 (927)

$2895(634)$

$1073(283)$
No. viable seeds $/ \mathrm{m}^{2}$

Top $5 \mathrm{~cm}$

$534(105)$

$235(84)$

$54(17)$
Viability (\%)

Bottom

$5 \mathrm{~cm}$

Top $5 \mathrm{~cm} \quad$ Bottom
$5 \mathrm{~cm}$

$185(86)$

$5.3(1.8) \quad 7.5(3.6)$

$99(30)$

$2.8(0.8) \quad 4.2(1.6)$

$45(12)$

$0.8 *(0.2) \quad 4.4(1.5)$

\section{Seedling establishment}

We conducted a survey of our plots at the burn site to document seedling regeneration, using a smaller plot size (radius $=0.8 \mathrm{~m}$, area $=2 \mathrm{~m}^{2}$ ) to avoid the locations where seed bank samples were taken. The surveys were done in late winter 1999, following the November 1998 burn and after germination was complete, to document the initial population of seedlings. Additional sampling was done in mid- and late spring for three years after the burn to determine further germination, as well as seedling survival. Firstyear germinants were $1-3 \mathrm{~cm}$ tall and distinguishable because cotyledons and two developing leaves were present. Seedlings that were $1.5 \mathrm{yr}$ old had lost cotyledons and developed several leaves, as well as slight woodiness at the base, but remained small ( $\sim 5-7$ $\mathrm{cm}$ tall) and single stemmed. Seedlings that were 2.5 $\mathrm{yr}$ old had begun to branch and had grown noticeably. A decrease in the number of individuals in a cohort from one year to the next was considered to be mortality, and survival was considered the inverse of this.

\section{RESULTS}

\section{Seed banks}

In 1995 , we sectioned 1808 seeds and found $4.7 \%$ to be viable $(6.4 \pm 1.9 \%$ viability per sample, mean \pm 1 SE; $n=10)$. In 1998, we sectioned 1271 seeds from preburn soil samples and found a total of $3.5 \%$ to be viable $(2.9 \pm 0.9 \%$ viability per sample; $n=14$. $)$. In both 1995 and 1998 preburn samples, there were significantly more seeds in the top $5 \mathrm{~cm}$ of soil than in the next $5 \mathrm{~cm}$ below it (Table 1; paired $t$ tests: 1995, $t$ $=3.12$, df $=4, P=0.04 ; 1998, t=3.98$, df $=6, P=$ $0.01)$. Although, on average, the viability of seeds was highest in the deeper samples, this difference was not statistically significant (paired $t$ test, $P>0.10$ for both.)

Fig. 3. Change in viable seed numbers in top and lower soil samples following the burn. Values are means $\pm 1 \mathrm{SE}(n=$ 7 ), estimated for $1 \mathrm{~m}^{2}$.

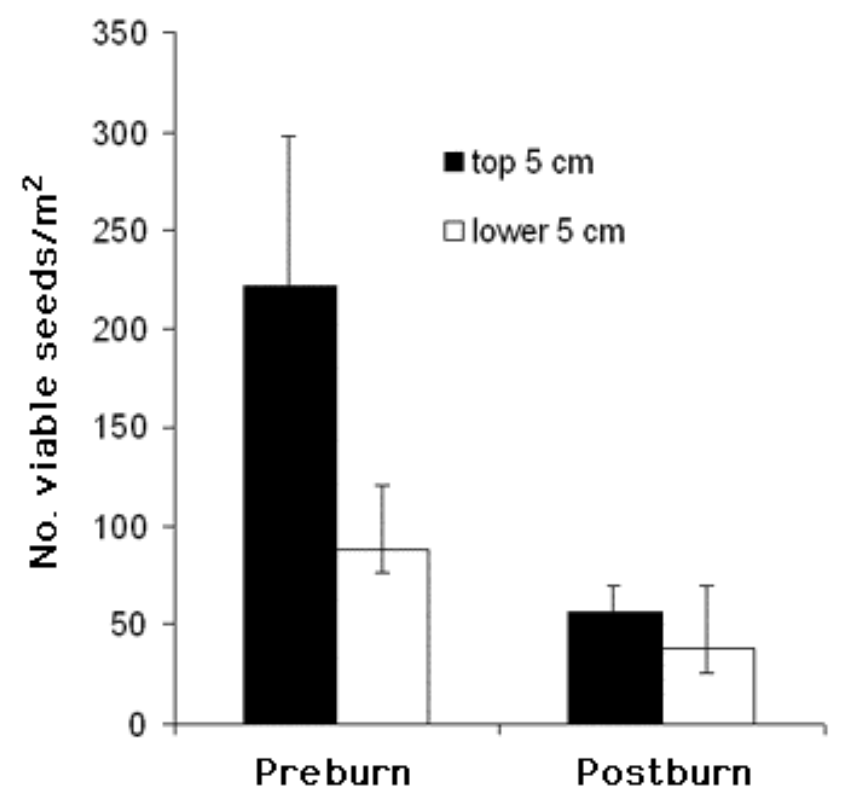


Fig. 4. Seedling establishment in 13 plots established in dense $A$. morroensis. Data are total numbers of $A$. morroensis seedlings per $2 \mathrm{~m}^{2}$ ) established in the first and second years after the prescribed burn done in November 1998, and censused in (a) April 2000 and (b) May 2001.

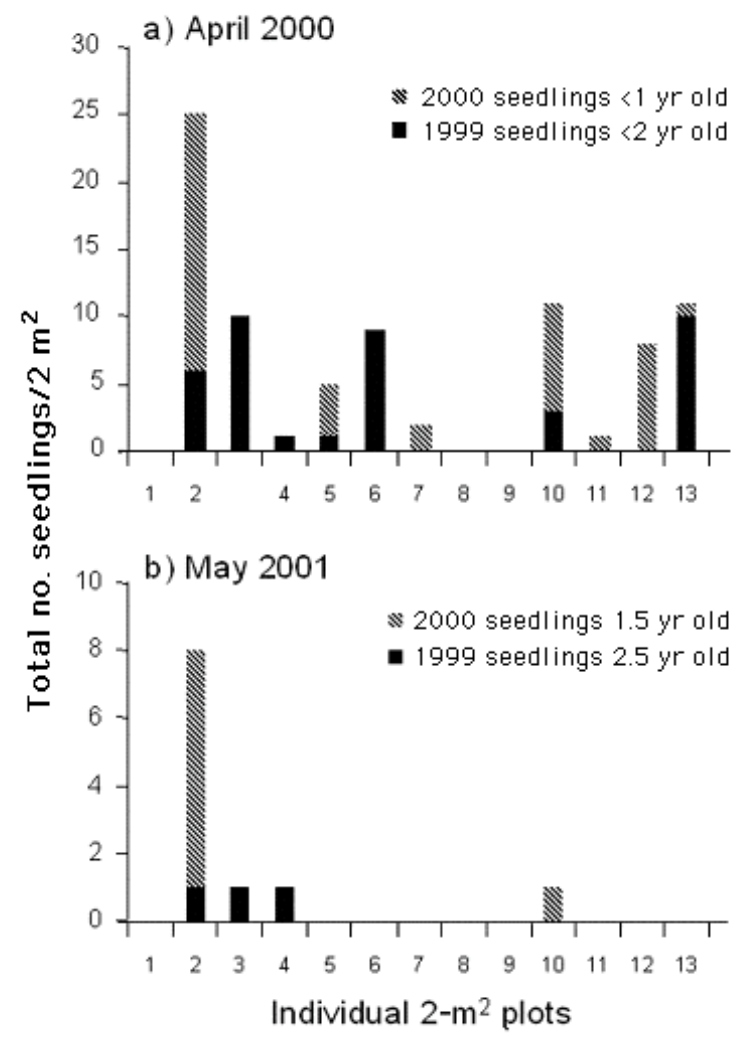

None of the 995 seeds from postburn samples germinated in the laboratory. When we sectioned them, we found that, although none had germinated, 11 were still viable. However, the number of viable seeds in top samples, where most seeds occur, was greatly reduced following fire (Fig. 3). On average, $77 \%$ of viable seeds were killed in the top $5 \mathrm{~cm}$ of soil (Table 1; mean of 235 viable seeds $/ \mathrm{m}^{2}$ in preburn samples vs. mean of 54 seeds $/ \mathrm{m}^{2}$ in postburn samples). Our results indicate that fire significantly reduced the percentage viability of seeds in top samples (Table 1 ): preburn seeds had mean $2.8 \%$ viability vs. mean $0.8 \%$ viability for postburn seeds; paired $t$ test, $P=0.04$ ). Interestingly, there was no significant change between pre- and postburn seed viabilities in the bottom samples.

\section{Seedling emergence and establishment in the burn area}

Germination in the A. morroensis plots was very patchy, with several plots devoid of any seedlings (Fig 4a). In 1999, the first spring following fire, there was an average of 1.5 seedlings $/ \mathrm{m}^{2}$. In year 2 , there was additional seedling germination: on average, 1.7 seedlings $/ \mathrm{m}^{2}$. There was no new germination in year 3 . Germination in year 1 was observed in four of the 11 plots located outside preburn A. morroensis patches. However, none of these germinants survived to year 2 .

The germination of seedlings in year 2 prevented virtual elimination of $A$. morroensis from the site, because mortality of the year 1 cohort was almost complete (Figs. $4 \mathrm{~b}$ and 5). Only $4 \%$ of the first-year cohort of seedlings survived to year 2 , whereas $21 \%$ of seedlings that germinated in year 2 survived to year 3 . All of the seedlings from the year 1 cohort that survived to year 2 also survived to year 3 . The wet February in year 2 was followed by a relatively wet spring and above-average June precipitation. The following rainy season commenced early and also had above-average precipitation (Fig. 1), so second-year germinants were subjected to a shorter, less severe summer drought than were those from year 1. Total precipitation amounts for each of the three years of the study were $72 \%, 110 \%$, and $108 \%$ of the $96-\mathrm{yr}$ average, respectively.

Three years after fire, there was less than half the number of A. morroensis seedlings ( 0.42 seedlings $\left./ \mathrm{m}^{2}\right)$ as there were adults before the fire $\left(0.91\right.$ adults $\left./ \mathrm{m}^{2}\right)$. Moreover, both in our plots and elsewhere, seedlings were in a clumped pattern (Fig. 4b; personal observation). Much of the area that formerly supported A. morroensis became devoid of it. Over time, there will probably be further mortality due to densitydependent thinning as a result of the clumped distribution of A. morroensis. For example, the highest density of adult $A$. morroensis in our plots prior to fire was 3 adults $/ \mathrm{m}^{2}$, far fewer than remained in plot 2 after 3 years. As a result of the burn (see Table 2), pure stands of the evergreen sclerophyll A. morroensis were transformed to stands of mostly mesophyllous shrubs and subshrubs (Artemisia californica, Mimulus aurantiacus, and Baccharis pilularis), as well as invasive aliens (the grass Ehrharta calycina) and two exotic iceplants (Conicosia pugioniformis and Carpobrotus edulis). The latter species of iceplant, an especially pernicious invader of maritime chaparral (D'Antonio et al. 1993), was not found in our plots, 
but mats of this succulent were beginning to establish in the burn area after three years.

Fig. 5. Mean density of first- and second-year cohorts of $A$. morroensisseedlings established in 13 plots that contained adult shrubs prior to the burn.

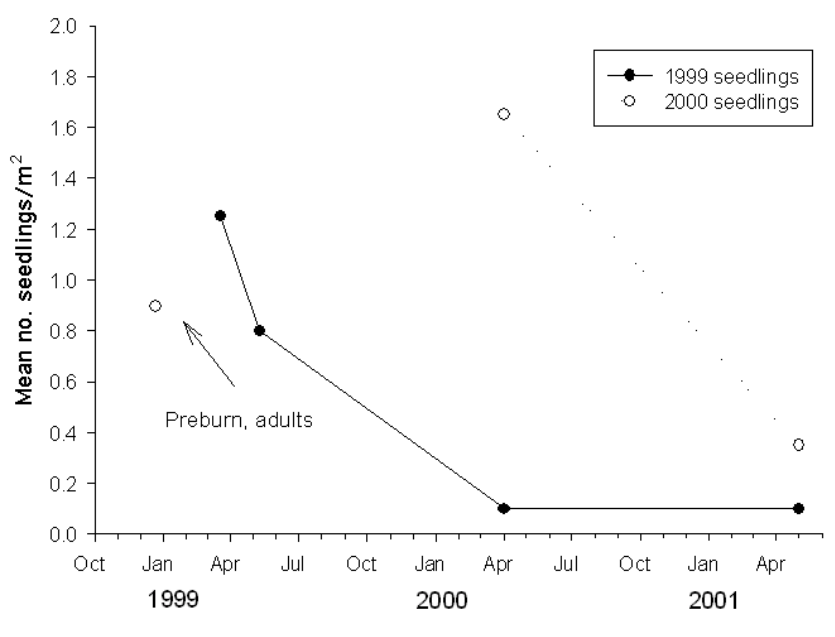

\section{DISCUSSION}

In the present study, the most likely causes for the failure of A. morroensis to reestablish at preburn densities following fire were: low initial percentage viability and destruction of seeds by fire, followed by high mortality of seedlings.

Based on a comparison of different-aged stands (C. Tyler and D. Odion, unpublished data), it appears that seed banks of $A$. morroensis continue to accumulate as stands develop. In some locations, A. morroensis seed densities in the soil may reach $45,000 \mathrm{seeds} / \mathrm{m}^{2}$ (C. Tyler and D. Odion, unpublished data), much greater than those reported from under other woody species in chaparral and other mediterranean-climate vegetation types (Parker and Kelly 1989, Odion 2000). However, we have documented that viability of $A$. morroensis seeds was especially low, ranging from $1 \%$ to $5 \%$. In contrast, studies of other obligate-seedling Arctostaphylos species have reported seed viabilities ranging from 6\% to 50\% (Keeley 1977, 1987, Kelly and Parker 1990). Thus, although seeds were abundant in the soil prior to fire, the number of viable seeds represented a small fraction of the apparent seed bank.

We found that viable seed populations in the upper 10 $\mathrm{cm}$ of soil were reduced by fire to less than one-third of preburn densities: from $\sim 325$ to $\sim 100$ seeds $/ \mathrm{m}^{2}$. We propose that the predominant cause of this loss was heat-induced mortality in the upper $5 \mathrm{~cm}$ of soil. Previous studies have documented significant seed loss due to fire in chaparral (Keeley 1977, Keeley 1987, Odion and Davis 2000), particularly near the soil surface (reviewed by Borchert and Odion 1995). The extreme temperatures of the fire that killed many seeds in the top $5 \mathrm{~cm}$ did not reduce viability in the lower $5 \mathrm{~cm}$ of soil. In a previous study conducted in similarly sandy soils, Odion and Davis (2000) found that although temperatures on the soil surface rose to $900-1000^{\circ} \mathrm{C}$, they reached only about $75^{\circ} \mathrm{C}$ at $5 \mathrm{~cm}$ depth, which is within the heat tolerance of Arctostaphylos species (e.g., Sampson 1944). Seeds must be buried at sufficient depth in the soil to survive fire, but not so deep that they remain dormant or fail to emerge after germinating because of insufficient carbohydrate reserves to support growth to the surface (Auld 1986, Bond et al. 1999). The portion of the seed bank that fits these specific depth-defined criteria is what contributes to the seedling population. The size and accumulation dynamics of this safe seed bank differ from those of the whole seed bank.

In fact, we found that $<1 \%$ of $A$. morroensis seedlings successfully germinated and emerged, compared to the total number of viable seeds in the soil after the burn (Table 3). This finding agrees with other studies (Keeley 1977, 1987, Odion 2000) that have compared Arctostaphylos seed densities to seedling populations after fire. Although some A. morroensis seeds may have been too deeply buried, those that were not may have failed to germinate and/or died prior to emergence, due to low soil moisture, particularly in year 1 , when every month after the November burn had well below average precipitation until March and April (Fig. 1). A. morroensis seeds that survived fire also may have failed to germinate and/or emerge due to subsequent attack by pathogens. It is also possible that some postburn seeds classified as viable in our study were damaged and incapable of germinating, leading to an overestimation of viable postburn populations, and/or that viable seeds remained dormant after fire for reasons independent of soil moisture. One or both of these could explain the complete lack of germination in our laboratory trial. Finally, postburn seed populations may have decreased from our estimate through predation between the time of the postburn seed bank collection and germination in the field (Quinn 1994). However. the germination response observed in year 2 indicates that early postburn seed predation did not decrease seed banks substantially. 
Table 2. Pre- and postburn cover and frequency (percentage of plots) of common species in 13 plots established under dense Arctostaphylos morroensis prior to fire. Invasive exotic species are denoted by the superscript $\mathrm{i}$.

\begin{tabular}{|c|c|c|c|c|c|c|}
\hline \multirow[b]{2}{*}{ Species } & \multicolumn{3}{|c|}{ Preburn } & \multicolumn{3}{|c|}{ Three years after fire } \\
\hline & $\begin{array}{c}\text { Mean } \\
\text { cover }(\%)\end{array}$ & $\begin{array}{c}\text { Frequency } \\
(\%)\end{array}$ & $\begin{array}{c}\text { Mean } \\
\text { density/m }\end{array}$ & $\begin{array}{c}\text { Mean } \\
\text { cover }(\%)\end{array}$ & $\begin{array}{c}\text { Frequency } \\
(\%)\end{array}$ & $\begin{array}{c}\text { Mean } \\
\text { density } / \mathrm{m}^{2}\end{array}$ \\
\hline \multicolumn{7}{|l|}{ Shrubs } \\
\hline $\begin{array}{l}\text { Arctostaphylo } \\
\text { s morroensis }\end{array}$ & 99.5 & 100 & 0.9 & $<1$ & 30 & 0.4 \\
\hline $\begin{array}{c}\text { Artemisia } \\
\text { californica }\end{array}$ & 0.4 & 8 & & 7 & 61 & \\
\hline $\begin{array}{l}\text { Baccharis } \\
\text { pilularis }\end{array}$ & 0 & 0 & & 4 & 38 & \\
\hline $\begin{array}{l}\text { Ceanothus } \\
\text { cuneatus }\end{array}$ & 0 & 0 & & $<1$ & 2 & \\
\hline \multicolumn{7}{|l|}{ Subshrubs } \\
\hline $\begin{array}{l}\text { Ericameria } \\
\text { ericoides }\end{array}$ & 0 & 0 & & $<1$ & 1 & \\
\hline $\begin{array}{l}\text { Eriophyllum } \\
\text { confertiflorum }\end{array}$ & $<1$ & 8 & & 1 & 1 & \\
\hline $\begin{array}{l}\text { Lotus } \\
\text { scoparius }\end{array}$ & 0 & 0 & & 5 & 23 & \\
\hline $\begin{array}{l}\text { Mimulus } \\
\text { aurantiacus }\end{array}$ & $<1$ & 8 & & 2 & 2 & \\
\hline $\begin{array}{l}\text { Solanum } \\
\text { umbelliferum }\end{array}$ & 0 & 0 & & 3 & 46 & \\
\hline \multicolumn{7}{|l|}{$\begin{array}{l}\text { Herbs and } \\
\text { grasses }\end{array}$} \\
\hline $\begin{array}{r}\text { Amsinkia } \\
\text { spectabilis }\end{array}$ & 0 & 0 & & 2 & 38 & \\
\hline $\begin{array}{l}\text { Chorizanthe } \\
\text { angustifolia }\end{array}$ & 0 & 0 & & 1 & 2 & \\
\hline $\begin{array}{l}\text { Claytonia } \\
\text { perfoliata }\end{array}$ & 0 & 0 & & 1 & 46 & \\
\hline $\begin{array}{l}\text { Conocosia } \\
\text { pugioniformis }\end{array}$ & 0 & 0 & & $<1$ & 15 & \\
\hline $\begin{array}{c}\text { Conyza } \\
\text { canadensis }\end{array}$ & 0 & 0 & & 1 & 1 & \\
\hline $\begin{array}{l}\text { Cryptantha } \\
\text { spp. }\end{array}$ & 0 & 0 & & 1 & 2 & \\
\hline $\begin{array}{l}\text { Ehrharta } \\
\text { calycina }^{\mathrm{i}}\end{array}$ & 0 & 0 & & 2 & 23 & \\
\hline $\begin{array}{l}\text { Gnaphalium } \\
\text { bicolor }\end{array}$ & 0 & 0 & & 2 & 23 & \\
\hline $\begin{array}{l}\text { Gnaphalium } \\
\text { ramosissimum }\end{array}$ & 0 & 0 & & 3 & 23 & \\
\hline
\end{tabular}


Table 3. Transitions of Arctostaphylos morroensis from seed to seedlings. Given are mean densities per square meter of preand postburn seeds in the top $10 \mathrm{~cm}$ of soil, and emerged and established seedlings. Also shown are the transition rates or percentage survival, calculated as the percentage change from the previous class.

\begin{tabular}{lll}
\hline Plant measurement & No. $/ \mathrm{m}^{2}$ & Survival (\%)
\end{tabular}

No. intact seeds preburn

No. viable seeds preburn

No. viable seeds postburn

Total no. emerged seedlings

Total no. established seedlings
11463

334

99

3.2

0.5
Even with the relatively poor germination response, there would have been adequate numbers of seedlings to replace adult $A$. morroensis with an equivalent-sized population if $47 \%$ of these seedlings had survived. Previous studies have documented that seedlings of obligate seeders typically have greater survivorship than those of sprouters, but still suffer considerable mortality (e.g., Sampson 1944, Horton and Kraebel 1955, Keeley and Zedler 1978, Tyler and D'Antonio 1995, Odion and Davis 2000). Water stress, especially during the first summer drought, is one important cause of death (Frazer and Davis 1988, Thomas and Davis 1989). Survivorship in these studies varied with site conditions, weather, and species. In maritime chaparral, Odion and Davis (2000) found that seedling mortality of the obligate-seeding Arctostaphylos purissima was $57 \%$ in the first year following fire and $89 \%$ after five years. Similar rates have been found among Arctostaphylos species at inland locations.

With $96 \%$ and $79 \%$ mortality of A. morroensis seedlings, respectively, for first- and second-year germinants, it appears that survival was very sensitive to precipitation and soil moisture. First-year seedlings may have germinated late because March was the month with the greatest precipitation (Fig. 1). Germination too close to the onset of summer drought would probably cause seedlings to be more vulnerable to moisture stress due to insufficient root development. For example, poor survival was shown in Adenostoma fasciculatum seedlings that germinated following a late-winter prescribed burn (Moreno and Oechel (1993). Conversely, moisture conditions for secondyear seedlings were favorable because of greater than average winter and spring precipitation and a shorter than average summer drought that followed. Thus, even under relatively favorable conditions, significant mortality due to drought stress, as found in our study and those just cited, appears likely. Moreover, it is likely that significant mortality will occur over time at our site because of density-dependent thinning among individuals in close proximity to one another (e.g., Schlesinger and Gill 1978). Thus, the low probability of transition of A. morroensis from seed to established individuals (Table 3 ) will decrease further.

\section{Conservation and management implications}

The seed bank that developed in the 40-yar-old stand that we studied was not sufficient to maintain population sizes of $A$. morroensis through the experimental burn. Clearly, the amount of seeds deep enough in the soil to survive fire must accumulate to much greater numbers to ensure that populations are maintained across fire cycles. Our studies of seed production minus initial seed predation (C. Tyler and D. Odion, unpublished data) have estimated that a minimum of 9-15 additional fire-free years would have been required for the whole seed bank to double in size from 1998 levels. Because we studied only one 
burn and there are uncertainties about seed bank dynamics, we cannot predict how much time is needed to provide a safe seed bank for A. morroensis. Our data suggest that stands $>40 \mathrm{yr}$ old may also be at risk.

A. morroensis probably evolved in an environment where its seeds could accumulate for relatively long intervals. With lightning and weather conditions conducive to combustion occurring relatively rarely, coastal chaparral environments north of the Transverse Ranges of southern California probably supported less frequent fire (e.g., 100-yr interval; Greenlee and Langenheim 1990) compared to inland counterparts ( 40-yr interval; Byrne et al. 1977, Mensing et al. 1999). Moritz (1997) has demonstrated that fire has been less frequent in chaparral where strong, warm, and dry winds from the interior are rare or absent, such as at the study site. A regime of infrequent fire may have selected for delay and/or reduced allocation to annual seed production in A. morroensis, especially if its cover increases with stand age, as has been found for other Arctostaphylos species in maritime chaparral (Davis et al. 1988).

In other North American vegetation types, most notably Southwest ponderosa pine forests, it has been documented that more frequent fire than presently occurs will be ecologically beneficial. Reintroducing fire and/or increasing fire frequency has received widespread recognition as a restoration imperative, as concerns over the effects of 20th-century fire suppression have grown. Selecting reference conditions for restoration may be complicated by past human influences, climate change, etc., which can result in the selection of a fire frequency that is not compatible with evolutionary history (Swetnam et al. 1998, Millar and Woolfenden 1999). Land managers are also increasingly turning to fire as a means of preventing fuel accumulation that results in greater fire hazard. As the present study illustrates, there are circumstances in which reintroducing fire and/or increasing fire frequency will have undesirable biological consequences. Managing fire in $A$. morroensis stands at a frequency typical of most chaparral areas ( $\sim 40$ years) could lead to the decline and eventual extinction of this species. There are a number of other rare obligate-seeding Arctostaphylos and Ceanothus species in maritime chaparral (Griffin 1978) and elsewhere that could be similarly affected.

In South Africa and Australia, many of the obligate seeders that dominate the shrublands do not have soilstored seed banks; rather, seeds are stored on plants in persistent fruiting structures. In these serotinous shrubs, the seed bank does not persist very long after the death of the parent (Lamont et al. 1991), and many species have been observed to have programmed senescence after reaching age 30-60 years (Bond 1980, Bond and van Wilgen 1996). Thus, fire intervals as long as those that appear to be required for $A$. morroensis maintenance could eliminate these obligate seeders. The fire interval that optimizes populations of one such serotinous shrub, Banksia hookeriana, has been found to be 16 years, based on detailed understanding of the dynamics of seed production, storage, and loss in relation to plant age (Enright et al. 1996, 1998). This reflects a regime of fairly frequent fire thought to be common over evolutionary time scales in much of South Africa and Australia (Pyne 1991, Bond and van Wilgen [1996] and references therein). Nonetheless, obligate seeders in the southern hemisphere, including those with soil-stored seeds, are also threatened by immaturity risk, and the persistence of a number of populations, species, and even plant associations has already been demonstrated to be endangered by anthropogenically increased fire frequency (e.g., Trollope 1972, Nieuwenhuis 1987, Enright et al. 1996, Russell-Smith et al. 2002). This may threaten chaparral in many areas as well (Keeley 2002).

The range of fire frequencies for which population maintenance may ultimately be possible in obligate seeders probably reflects the recent evolutionary history of fire, because of the potential for these species to evolve relatively rapidly in response to environmental change (Wells 1969). However, obligate seeders, in general, appear to have little resilience to human-imposed fire regimes that diverge from recent evolutionary history, and this may apply to A. morroensis. Of greatest concern globally to the conservation of the numerous rare taxa that characterize the obligate-seeding life history is both increased fire frequency resulting from intentional burning (Russell-Smith et al. 2002) and exotic species invasion (e.g., Zedler et al. 1983).

\section{Conclusion}

The conservation of many obligate-seeding species and their shrubland associates may depend on whether the parameters of fire regimes that are compatible with their evolutionary history can be identified and successfully maintained. In many cases, fire frequencies may need to be decreased. 
Responses to this article can be read online at: http://www.consecol.org/vol6/iss2/art4/responses/index.html.

\section{Acknowledgments:}

Constructive comments on the manuscript were provided by Mark Borchert, Joe Connell, Diana Hickson, Marcia Pinneau, and two anonymous referees. This research was supported by the California Department of Fish and Game, Species Conservation and Recovery Program. We thank Sandra Morey, Diana Hickson, and Deborah Hillyard for initiating the project and for their support and insights throughout its duration. We are grateful to Vince Cicero for his assistance with all aspects of the prescribed burn. Daniel Meade, Max Moritz, and Nicole Palkovsky provided invaluable assistance in the field. We also thank the staff at UCSB's Marine Science Institute, especially Marie Ciluaga, Judy McCaslin, and Arlene Phillips, for their administrative support.

\section{LITERATURE CITED}

Auld, T. D. 1986. Population dynamics of the shrub Acacia suaveolens (Sm.) Willd.: fire and the transition to seedlings. Australian Journal of Ecology 11:373-385.

Auld, T. D., and A. J. Denham. 2001. The impact of seed predation by mammals on post-fire seed accumulation in the endangered shrub Grevillea caleyi (Proteaceae). Biological Conservation 97:377-385.

Bond, W. J. 1980. Fire and senescent fynbos in the Swartberg, Southern Cape. South African Forestry Journal 114:68-71.

Bond, W. J., M. Honig, and K. E. Maze. 1999. Seed size and seedling emergence: An allometric relationship and some ecological implications. Oecologia 120:132-136.

Bond, W. J., and B. W. van Wilgen. 1996. Fire and plants. Chapman and Hall, London, UK.

Borchert, M. I., and D. C. Odion. 1995. Fire intensity and vegetation recovery in chaparral: a review. Pages 91-100 in J. E. Keeley and T. Scott, editors. Brushfires in California: ecology and resource management. International Association of Wildland Fire, Fairfield, Washington, USA.

Byrne, R. J., J. Michaelson, and A. Soutar. 1977. Fossil charcoal as a measure of wildfire frequency in southern California: a preliminary analysis. Pages 361-367 in H. A. Mooney and C. E. Conrad, editors. Proceedings of the Symposium on Environmental Consequences of Fire and Fuel Management in Mediterranean Ecosystems. U.S. Forest Service General Technical Report WO-3.

Craddock, G. W. 1929. The successional influence of fire on the chaparral type. Thesis. University of California,
Berkeley, California, USA.

D’Antonio, C. M., D. C. Odion, and C. M. Tyler. 1993. Invasion of maritime chaparral by the alien succulent Carpobrotus edulis: the role of fire and herbivory. Oecologia 95:14-21.

Davis, F. W., D. E. Hickson, and D. C. Odion. 1988. Composition of maritime chaparral related to fire history and soil, Burton Mesa, California. Madroño 35:169-195.

Enright, N. J., B. B. Lamont, and R. Marsula. 1996. Canopy seed bank dynamics and optimum fire regime for the highly serotinous shrub, Banksia hookeriana. Journal of Ecology 86: 960-973.

Enright, N. J., R. Marsula, B. B. Lamont, and C. Wissel. 1998. The ecological significance of canopy seed storage in fire-prone environments: a model for non-sprouting shrubs. Journal of Ecology 86:946-959.

Frazer, J. M., and S. D. Davis. 1988. Differential survival of chaparral seedlings during the first summer drought after wildfire. Oecologia 76:215-221.

Greenlee, J. M., and J. H. Langenheim. 1990. Historic fire regimes and their relation to vegetation patterns in the Monterey Bay Area of California. American Midland Naturalist 124:239-253.

Griffin, J. R. 1978. Maritime chaparral and endemic shrubs of the Monterey Bay region, California. Madroño 25:65-81.

Hartford, R. A., and W. H. Frandsen. 1992. When it's hot, it's hot ... or maybe it's not! (Surface flaming may not portend extensive soil heating). International Journal of Wildland Fire 2:139-144.

Horton, J. S., and C. J. Kraebel. 1955. Development of vegetation after fire in the chamise chaparral of southern California. Ecology 36:244-262.

IUCN (International Union for the Conservation of Nature, or World Conservation Union). 1994. IUCN Red List Categories. IUCN Species Survival Commission, Gland, Switzerland.

Keeley, J. E. 1977. Seed production, seed populations in soil, and seedling production after fire for two congeneric pairs of sprouting and nonsprouting chaparral shrubs. Ecology 58:820-829.

Keeley, J. E. 1987. Ten years of change in seed banks of the chaparral shrubs, Arctostaphylos glauca and $A$. glandulosa. American Midland Naturalist 117:446-448.

Keeley, J. E., editor. 1993. Interface Between ecology and land development in California. Southern California Academy of Sciences, Los Angeles, California, USA.

Keeley, J. E. 2002. Fire management of California shrubland landscapes. Environmenatal Management 
29:395-408.

Keeley, J. E., M. Baer-Keeley, and C. J. Fotheringham. 2000. Second interface between ecology and land development in California. U.S. Geologic Survey. Open-file Report 00-62. Sacramento, Califoria, USA.

Keeley, J. E., C. J. Fotheringham, and M. Morias. 1999a. Reexamining fire suppression impacts on brushland fire regimes. Science 284:1829-1832.

Keeley, J. E., G. Ne'eman, and C. J. Fotheringham. 1999b. Immaturity risk in a fire-dependent pine. Journal of Mediterranean Ecology 1:41-48.

Keeley, J. E., and P. H. Zedler. 1978. Reproduction of chaparral shrubs after fire: a comparison of sprouting and seeding strategies. American Midland Naturalist 99:142161.

Keith, D. A. 1998. An evaluation and modification of World Conservation Union Red List criteria for classification of extinction risk in vascular plants. Conservation Biology 12:1076-1090.

Kelly, V. R., and V. T. Parker. 1990. Seed bank survival and dynamics in sprouting and nonsprouting Arctostaphylos species. American Midland Naturalist 124:114-123.

Lamont, B. B., D. C. Le Maitre, R. M. Cowling, and N. J. Enright. 1991. Canopy seed storage in woody plants. Botanical Review 57:277-317.

Mensing, S. A., J. Michaelsen, and R. Byrne. 1999. A 560-year record of Santa Ana fires reconstructed from charcoal deposited in the Santa Barbara Basin, California. Quaternary Research 51:295-305.

Millar, C. I., and W. B. Woolfenden. 1999. The role of climate change in interpreting historical variability. Ecological Applications 9:1207-1216.

Moreno, J. M., and W. C. Oechel. 1993. Demography of Adenostoma fasciculatum after fires of different intensities in southern California chaparral. Oecologia 96:95-101.

Moritz, M. A. 1997. Analyzing extreme disturbance events: fire in the Los Padres National Forest. Ecological Applications 7:1252-1262.

Mullany, M. 1990. The distribution and variation of Arctostaphylos morroensis (Ericaceae). Thesis. California State Polytechnic University, San Luis Obispo, California, USA.

Ne'eman, G., C. J. Fotheringham, and J. E. Keeley. 1999. Patch to landscape patterns in post fire recruitment of a serotinous conifer. Plant Ecology 145:235-242.

Nieuwenhuis, A. 1987. The effect of fire frequency on the sclerophyll vegetation of the West Head, new South Wales. Australian Journal of Ecology 12:373 -385.
Odion, D. C. 2000. Seed banks of long-unburned stands of maritime chaparral: composition, germination behavior, and survival with fire. Madroño 47:195-203.

Odion, D. C., and F. W. Davis. 2000. Fire, soil heating, and the formation of vegetation patterns in chaparral. Ecological Monographs 70:149-169.

Parker, V. T., and V. R. Kelly. 1989. Seed banks in California chaparral and other Mediterranean climate shrublands. Pages 231-255 in M. A. Leck, V. T. Parker, and R. L. Simpson, editors. Ecology of soil seed banks. Academic Press, San Diego, California, USA.

Pyne, S. J. 1991. Burning bush: a fire history of Australia. Henry Holt, New York, New York, USA.

Quinn, R. D. 1994. Animals, fire, and vertebrate herbivory in Californian chaparral and other mediterranean-type ecosystems. Pages 46-78 in J. M. Moreno and W. C. Oechel, editors. The role of fire in mediterranean-type ecosystems. Springer-Verlag, New York, New York, USA.

Russell-Smith, J., P. G. Ryan, and D. C. Cheal. 2002. Fire regimes and the conservation of sandstone heath in monsoonal northern Australia: frequency, interval, patchiness. Biological Conservation 104:91-106.

Sampson, A. W. 1944. Plant succession on burned chaparral lands in northern California. University of California Agricultural Experiment Station Bulletin 685.

Schlesinger, W. H., and D. S. Gill. 1978. Demographic studies of the chaparral shrub, Ceanothus megacarpus, in the Santa Ynez Mountains, California. Ecology 61:781-789.

Soil Conservation Service. 1984. General soil map. San Luis Obispo County, California, coastal part. U.S. Department of Agriculture, Washington, D.C., USA.

Swetnam, T. W., C. D. Allen, and J. L. Bentancourt. 1998. Applied historical ecology: using the past to manage for the future. Ecological Applications 9:1189-1206.

Thomas, C. M., and S. D. Davis. 1989. Recovery patterns of three chaparral shrub species after wildfire. Oecologia 80:309-320.

Trollope, W. S. W. 1972. Fire as a method of eradicating macchia vegetation in the Amatole Mountains of South Africa. Proceedings of the Tall Timbers Fire Ecology Conference 11:99-120.

Tyler, C. M. 1995. Factors contributing to postfire seedling establishment in chaparral: direct and indirect effects of fire. Journal of Ecology 83:1009-1020.

Tyler, C. M., and C. M. D'Antonio. 1993. The effects of neighbors on the growth and survivorship of shrub seedlings following fire. Oecologia 102:255-264. [See Erratum]

Wells, P. V. 1969. The relation between mode of 
reproduction and extent of speciation in woody genera of the California chaparral. Evolution 23:264-267.

Zedler, P. H. 1995. Fire frequency in southern California shrublands: biological effects and management options. Pages 101-112 in J. E. Keeley and T. L. Scott, editors. Brushfires in California: ecology and management. International Association of Wildland Fire, Fairfield, Washington, USA.

Zedler, P. H., C. R. Gautier, and G. S. McMaster. 1983. Vegetation change in response to extreme events: the effect of a short interval between fires in California chaparral and coastal scrub. Ecology 64:809-818.

ERRATUM (1). In the original published version of this article, the reference to Tyler and D'Antonio 1993 is erroneous.

Tyler, C. M., and C. M. D'Antonio. 1993. The effects of neighbors on the growth and survivorship of shrub seedlings following fire. Oecologia 102:255-264.

The correct citation is for Tyler and D'Antonio 1995 as follows:

Tyler, C. M., and C. M. D'Antonio. 1995. The effects of neighbors on the growth and survivorship of shrub seedlings following fire. Oecologia 102:255-264.

ERRATUM (2). In the original published version there is a mispelling of the word "year" in the sentence:

The seed bank that developed in the 40-yar-old stand that we studied was not sufficient to maintain population sizes of $A$. morroensis through the experimental burn.

The correct sentence is as follows:

The seed bank that developed in the 40-year-old stand that we studied was not sufficient to maintain population sizes of $A$. morroensis through the experimental burn. 